\title{
Reflecting upon 30 Years of STEM Partnerships between Industry, University, and Public Schools: Past Lessons, Current Successes, and Future Dreams
}

\author{
Lisa A. Dieker*(D), Malcolm B. Butler, Enrique Ortiz and Su Gao
}

check for

updates

Citation: Dieker, L.A.; Butler, M.B.; Ortiz, E.; Gao, S. Reflecting upon 30 Years of STEM Partnerships between Industry, University, and Public Schools: Past Lessons, Current Successes, and Future Dreams. Educ. Sci. 2021, 11, 760. https:// doi.org/10.3390/educsci11120760

Academic Editors: Andrea Burrows and Mike Borowczak

Received: 17 September 2021 Accepted: 14 November 2021 Published: 24 November 2021

Publisher's Note: MDPI stays neutral with regard to jurisdictional claims in published maps and institutional affiliations.

Copyright: (c) 2021 by the authors. Licensee MDPI, Basel, Switzerland. This article is an open access article distributed under the terms and conditions of the Creative Commons Attribution (CC BY) license (https:/ / creativecommons.org/licenses/by/ $4.0 /)$.
School of Teacher Edcuation, University of Central Florida, Orlando, FL 32816, USA; malcolm.butler@ucf.edu (M.B.B.); enrique.ortiz@ucf.edu (E.O.); su.gao@ucf.edu (S.G.)

* Correspondence: lisa.dieker@ucf.edu

\begin{abstract}
The importance of partnerships is critical in educational arenas, but information on how partnerships form with the involvement of corporations, districts, and universities working in harmony is limited in the current literature. The teacher preparation program described in this paper is a "built-to-last" partnership model with over 650 teachers prepared to be teacher-leaders in science, technology, engineering, and mathematics (STEM) education. The authors provide a history of the program's development, the sustainability of the program over time, the content of the various components of the partnership, and the evolution of the program, including its current status.
\end{abstract}

Keywords: STEM; teacher preparation; partnership; diverse learners

\section{The Literature Framing the Partnership}

Finding innovative ways to keep teachers in the field while promoting the overall impact on student learning is the theme of this article. The authors highlight a current partnership between a university, a large corporation, and surrounding school districts. The focus of this partnership emerged and continues today to address key variables noted in the literature as to why teachers leave the field: (1) lack of preparation for the content (e.g., mathematics and science), (2) lack of preparation for pedagogical practices to ensure student engagement and learning outcomes [1], and (3) high rates of stress and burnout [2]. Research on teacher preparation indicates a need to support teachers in both learning the content and creating a classroom culture that engages students [3,4]. The stress on teachers has increased over the years, especially in STEM content areas, as they strive to meet the needs of a more diverse set of learners who are expected to meet and even exceed local, state, and national standards [5-7].

Despite high expectations for outcomes and rigorous learning standards, Banilower et al. suggest a flat trajectory in adjusting to major reform efforts in teaching practices aligned with these expectations [8]. With the stakes high for learning outcomes for both teachers and students alike in STEM areas, one approach to addressing this increasing stress began in 1992 through a partnership formed between a university and an industry partner. This partnership impacted and will continue to forever influence teachers with regard to leadership, retention, and increasing student learning outcomes. The program also focuses on advancing teacher knowledge in terms of both content and pedagogical practices. The authors of this article provide the field with a summary of this "built-to-last" [9] mindset underlying this teacher preparation program built through sustained partnerships. They provide the literature grounding the principles of the program, the domains of the content of the program, and the demographic and evaluation data documenting the success of the program. In addition, they provide a history of the program's development, the sustainability of the academy over time, the intricacies of the partnership, and the progress of the program in serving a range of teachers in STEM areas. 
The University of Central Florida (UCF) and Lockheed Martin Mathematics and Science Academy (LMA) began in 1992 with one program focused on retooling and preparing $\mathrm{K}-8$ teacher-leaders in mathematics and science. Today, the LMA program has expanded to three different venues, with each built upon increasing teachers' skills in three domains: (1) mathematics instruction, (2) science instruction, and (3) teacher leadership in meeting the needs of diverse learners. The program faculty members have responded to the shift in standards as well as the stress of being a teacher by creating a cohort program. The local school districts view the program as one of many strategies to prepare, retain, and further promote teacher leadership. The work of the LMA is aligned with attracting, retaining, and recruiting the best and brightest to teaching, with a specific focus on retooling and enhancing skills in STEM-related content.

The LMA team responds to this need for retooling as one of many ways to address the exorbitant cost of teacher turnover, being at least $\$ 2.2$ billion per year [10]. As CarverThomas and Darling-Hammond emphasized, the creation of the annual demand for teachers comes not from a shortage of preparing enough but from the almost immediate exiting of those prepared [11]. An annual poll by Phi Delta Kappa further showed over half of teachers wanting to leave the field, with $19 \%$ of those citing stress, pressure, or burnout as the primary reason [12]. Elementary teachers specifically struggle with being prepared and feeling they are adequate at teaching STEM content [13]. In contrast to these findings, the typical LMA scholar remains in teaching for eight or more years, with over $60 \%$ who are eligible to retire staying throughout their career [14].

The LMA team is grounded in closing gaps of confidence in STEM content or those who might have content expertise but fail to know how to address a wide range of learners' needs in their areas of expertise [15-17]. The LMA faculty also ground their thinking in an important element of successful inquiry in mathematics or science, ensuring student engagement in discourse [18]. The academy faculty embrace the concept of discourse, with their foundation in the social and cultural views of the ways people linguistically interact. Gee defines discourse as the combination of the conversation paired with the interactions or ways of acting that emerge from unique conversations [19]. Gee's definition insists discourse orchestrates change and understanding from an exchange of ideas. A teacher's ability to allow for the process of inquiry along with discourse increases a student's ability to engage with the content and retain information [20]. The domains of instruction within the academy are framed in the power of discourse led by teachers who help to elevate students' voices, understandings, and learning outcomes in the critical areas of STEM. Many of the academy scholars are working with diverse learners, with 125 teachers currently in the K-8 Mathematics and Science Education M.Ed. program and the Transition to Mathematics and Science Teaching (TMAST) being employed in Title I schools.

\section{Methods and Materials: The Solution to Today's Issues Began 30 Years Ago}

The formation of this academy is one that is unique and somewhat of an anomaly in the partnership with UCF, the Lockheed Martin Corporation (LMCO), and local school districts sustaining this program over the past 30 years [21]. The authors provide a history of the development of the program from both program archival data and ongoing annual external evaluations to help others understand the power of true industry, university, and district partnerships [21]. The academy team notes that these relationships take time to both develop and sustain while maintaining a positive reputation for all involved. Most importantly, the academy, its faculty members, and its teachers have retooled themselves as standards changed, the needs of the community changed, and even priorities changed (e.g., teacher shortages). For example, the 2008 economic recession hit Florida very hard, being ranked as the 48th state with the greatest loss in revenue [14], and the academy team pivoted to address layoffs in STEM areas to fill gaps in shortages of teachers. During the recent COVID-19 pandemic, the team shifted again to think about teacher leadership in STEM content through virtual and socially distanced settings. One of the lessons learned by the academy leadership team was that with a strong foundation, shifts can happen 
with a program built upon a shared community of problems and with investments by all partners involved (i.e., industry, districts, and the university).

The directors of the academy documented the creation and evolution of the academy through historical records at UCF. The academy formed in 1992 when LMCO, who built two major facilities in the Central Florida area, realized the pending shortages they would encounter in engineers in Central Florida and nationwide. The LMCO, in response to a need for more engineers, offered several large grants to increase the supply chain of students prepared with advanced STEM content skills in the early elementary grades to enter advanced STEM content aligned with engineering degrees. Therefore, LMCO provided substantial funding to key universities to impact the trajectory of students in STEM fields. The University of Central Florida applied for and was awarded a grant for USD one million to support teacher development in Central Florida STEM education. The UCF leadership in 1992 had a vision for this USD one million grant and asked if funds from the LMCO could be endowed instead of provided as a grant. The UCF leadership team informed the LMCO leaders that if the gift was over USD one million, the state would provide a $50 \%$ match. Therefore, the final check, given in 1992 to UCF, was for USD $1,000,001$, with a USD 500,000 match from the state collectively going into an endowment. This idea of a corporation providing funding to teacher education through an endowment was a novel, creative, and impactful concept that today provides never-ending funds from the interest of the initial gift. The process to endow these funds instead of receiving a grant and garnering a match from the state took several rounds of negotiations between legal teams. The outcome in 1992 was, and today still is, a sustained, innovative, and most importantly impactful program to "forever" support $\mathrm{K}-8$ teachers as leaders in STEM and the students they teach in the Central Florida community.

This university, corporate, and school district partnership has reaped additional benefits beyond this sustained program. Originally, the program, endowed in 1992, was set to begin in 1996, when the interest from the USD 1,501,000 reached a level to support the first cohort of teachers. However, the UCF leadership team leveraged this partnership investment to approach the National Science Foundation (NSF) for a grant to fund cohorts of teachers until the endowment matured. The funds garnered from the NSF afforded the academy the opportunity to support teachers immediately. Thus, from 1992 to 1996, over 60 scholars graduated while the endowment grew. This initial gift, along with funds from the NSF, jump-started the program while allowing this foundational funding to maintain a program 30 years later.

\section{Reflections on the Evolution of the Partnership}

\subsection{University of Central Florida and Lockheed Martin Academy Programs}

The University of Central Florida was founded in 1963, with its first class graduating in 1969. In juxtaposition, today, the university is eligible for Title II funding as a Hispanic-serving institution (over $27 \%$ of students are of Hispanic culture) and has over 70,000 students enrolled [22]. The university, even in 1992, was well-positioned to support the mission of the LMA with an increasingly large teacher preparation program. The LMA program is an education, industry, and community partnership aimed at improving STEM education in Central Florida. This unique partnership serves as a model for the educational reforms proposed by both national and state agencies by providing schools in Central Florida with teacher-leaders who initiate, implement, and sustain STEM reform efforts. The profile for the funding and support of LMA includes the following:

(a) The LMCO provides the stimulus for the development of the LMA concept through an endowment to ensure the longevity of the program;

(b) The Board of Regents of the State University System (SUS) of Florida provides matching funds to attain the LMA's goals;

(c) The University of Central Florida commits to support the development of the academy through new faculty lines, priority course scheduling, and faculty support. 
Although the initial gift to the academy was to fill the gap for K-8 teachers in STEM areas, since 2004, the LMCO granted two additional gifts to the UCF LMA to create additional programs to impact teachers in Central Florida: the Transition to Mathematics and Science Teaching (TMAST) program and the K-8 Teacher Enhancement program. Components of each of the three programs that grew from this initial partnership are provided.

\section{2. $K-8$ Program}

The mission of the K-8 Mathematics and Science Education M.Ed. degree is to improve the quality of mathematics and science teaching in Central Florida through (1) strengthening the quality of teaching and learning in STEM, (2) creating a network of school-based leadership in STEM, and (3) increasing the number of students choosing to enroll in STEM courses aligned with careers in STEM-related fields.

In this context, the teachers in the $\mathrm{K}-8$ program participate in six semesters of coursework, with six credits each semester (Table 1). The teachers enter the program in a cohort and complete the courses together while teaching full time in their respective districts. All teachers recruited into the program must have three or more years of teaching experience, have an undergraduate GPA of over 3.0, complete a summary of their teacher leadership experiences, and provide a required letter from their current administrator. The teachers complete a series of courses found in Table 1 reflecting the program foci of (1) mathematics, (2) science, and (3) leadership for diverse learners.

Table 1. Components of the UCF and Lockheed Marting program and course sequence (K-8 Graduate Program).

\begin{tabular}{|c|c|}
\hline Semester & Courses \\
\hline & $\begin{array}{l}\text { Space and Physical Science for Educators } \\
\text { Problem Solving and Critical Thinking Skills }\end{array}$ \\
\hline 2 & $\begin{array}{l}\text { Data-Driven Decision Making for Instruction } \\
\text { Reforming Curriculum in Mathematics and Science Education }\end{array}$ \\
\hline 3 & $\begin{array}{c}\text { Seminar in Teaching Mathematics } \\
\text { Seminar in Critical Issues in Special Education }\end{array}$ \\
\hline 4 & $\begin{array}{l}\text { Environmental Education for Educators } \\
\text { Leadership Development for Mathematics and Science Teachers }\end{array}$ \\
\hline 5 & $\begin{array}{l}\text { Current Methods in Elementary School Mathematics } \\
\text { Research in Mathematics and Science Education }\end{array}$ \\
\hline 6 & $\begin{array}{c}\text { Teaching Mathematics and Science Using Reform-Based Practices } \\
\text { Quality Teaching Practices (Action Research Capstone Course) }\end{array}$ \\
\hline
\end{tabular}

Mathematics Components (Table 1). When conceptualized, the K-8 program includes a core component in mathematics, and this component continues to evolve today. This aspect of the program includes three integrated courses with an emphasis on scholars' pedagogical content knowledge and utilization of project-based learning activities (PBL). One of the courses is a seminar in teaching mathematics, which presents the development of historical and current issues, forces, and the impact of the teacher on student learning through advanced instructional techniques (e.g., cooperative learning, discourse, and noticing). The second course is about current methods in elementary school mathematics. This course includes strategies of instruction, of computation and concepts of numbers, geometry, measurement, algebra, and professional standards for teaching mathematics. The third course is about problem-solving and critical thinking skills. The faculty member in this course emphasizes the development of procedures and practices to implement critical thinking skills and problem-solving techniques for learning.

These courses have two common threads: pedagogical content knowledge and PBL. The emphasis on scholars' development of pedagogical content knowledge goes beyond 
mathematics knowledge. The teachers' deep understanding of mathematical content is necessary but not sufficient to teach mathematics effectively. Shulman stated that pedagogical content knowledge is used by effective teachers when they possess an indepth knowledge of how to effectively represent the subject matter to learners [23,24]. Additionally, pedagogical content knowledge should include teachers' knowledge of learners' needs, learning styles, environments, goals, purposes, and values. The LMA team encourages scholars to develop the ability to transform mathematics content into pedagogically powerful learning activities for the students' diverse learning abilities and backgrounds in their classrooms [23].

The core use of PBL allows teachers to create and implement learning activities that support their development of pedagogical content knowledge. The PBL method allows students to learn by actively engaging in real-world and personally meaningful projects. The scholars learn about PBL by experiencing this type of approach throughout their courses. The scholars in evaluations of the program note the power of learning by example and reflecting upon the deep learning they experience using this approach.

Science Components (Table 1). The designers of the $\mathrm{K}-8$ program also realized the need to have a strong science component in the program. The result was two contentfocused course offerings aligned with the science taught in elementary and middle schools. Both courses provide opportunities for teachers to view science through the lens of a learner, instructor, and leader. The two courses take advantage of the plethora of informal science-based settings at the university and in the central Florida region. Additionally, the two courses are taken during different semesters so the scholars can have time to process and refine their instructional skills around the teaching of science.

The first course emphasizes environmental science. During the weeks of this course, the scholars are engaged in numerous activities requiring them to re-visit their current instruction related to nature and the environment. Collectively and individually, scholars are challenged to consider how they might use learners' local communities in the science classroom. Field trips to local places help scholars to "connect the dots". Several action research projects have this course as their genesis.

The second science course focuses on physical and space science. Similar to the environmental science course, scholars experience science in ways that their students might. Notably, these science topics are taught with the understanding they could be difficult topics for the scholars [25]. For example, the scholars visit the Kennedy Space Center and its education center, which is typically the highlight of this course. Scholars come away from this course with a deeper understanding and appreciation for physical science and space science, as well as how to help young learners appreciate and understand these science content areas.

Teacher Leadership and Diverse Learners (Table 1). The third set of courses prepares scholars to serve as leaders in meeting the needs of all learners, with a particular emphasis on those underrepresented in STEM. This component includes a sequence of courses on leadership combined with specific courses on leadership in mathematics and science inquiry. This component of the program also includes a course on current issues and trends in special education, inclusive of topics of diversity, universal design for learning, and creating inclusive leadership within the district. This portion of the program concludes with a two-course sequence focused on teachers as researchers to lead change. These courses require the participants to conduct an in-depth literature review aligned with their desired action research study in their final semester.

The K-8 program is evaluated by an external evaluator every 2 years. The program consistently receives outstanding reviews by the scholars. Any area of concern that arises is addressed by the leadership team. The team conducts an extensive review bi-annually, but each semester they review course evaluations to update content or seek more effective instructors, if necessary. Additionally, course instructors listen to scholars' feedback throughout the program to ensure the best outcome for the teachers in meeting the needs of 
their learners in STEM areas. Provided in Table 2 are a few select comments from scholars about the program [21].

Table 2. Comments from UCF and Lockheed Martin program scholars.

\begin{tabular}{c}
\hline Comments about the Most Valuable Outcome of the Program for Learning [21] \\
\hline "Being able to apply the learned contents into my classroom, regardless of their abilities." \\
"The new learning strategies I can now apply to my teaching." \\
"Focus on science and math." \\
"Cohort instruction, reasonable schedule with teaching." \\
"The professors' active knowledge about current classroom situations and state standards." \\
"The program has given me the confidence to be a leader in mathematics, and I feel more \\
confident teaching science when I didn't before this program." \\
"I loved the professors' passion \& investment in each of us, along with their inspirational \\
knowledge base. I liked that everything was immediately applicable to my classroom as well." \\
"I liked learning new strategies and the way we should develop the class." \\
"I liked meeting with and learning from knowledgeable professors, as well as working with \\
distinguished colleagues throughout OCPS."
\end{tabular}

Action Research Project. The culminating aspect of the program is an action research project. Scholars begin to conceptualize this project upon entering the program and build upon a topic of choice throughout the six semesters. The action research is framed in a variety of methodologies inclusive of gathering data in a perceived area of current weakness in their classrooms and schools in STEM. Unlike more formal research master's theses, action research is typically within the school or classroom, but in the LMA, these practices are specifically targeted in areas of teacher leadership for diverse learners in STEM content. The action research process involves less-formal, theory-driven methodologies. The goal of the LMA faculty members is to help teacher-leaders in the program address practical problems in their specific school or classroom [26]. The general goal of the culminating activity of the action research project is to find a practical approach to improving learning outcomes in STEM.

The process LMA teacher scholars engage in for their action research projects within the academy follows predefined steps built upon the work of numerous researchers in the field [26-31]. These steps begin in their fifth semester and culminated with a presentation of their work in the sixth and final semester. The steps used to guide the action research studies are (1) identify the problem, (2) develop a data-driven plan to address a problem focused on impacting student learning in STEM, (3) implement the plan, (4) collect data on the identified problem aligned with STEM learning, (5) organize, analyze, and interpret the collected data on STEM learning, (6) evaluate the results of the action taken and make further changes beyond the findings to ensure a mindset of constant change and future leadership in impacting student learning outcomes, and (7) conclude the project by determining the identified but still unresolved problems and future plans. The outcome of this systematics process is to ensure these teachers are prepared as ongoing teacher-leaders to impact the outcomes of diverse learners in STEM content.

Since the fall semester of 2019, LMA scholars have completed action research projects as part of their capstone project requirement of the program. Prior to 2019, scholars completed a more traditional master's thesis, which is still an option today. For the action research project, scholars can individually or in small collaborative groups of 3-4 scholars complete their projects. Since 2019, a total of 106 scholars have completed action research projects analyzing issues or challenges in their own classroom teaching practices in STEM areas. An action research project includes elaboration of research questions, selection and application of research methodologies, a literature review, implementation of a research plan, data collection, and analysis. As part of the capstone course, the culminating activities 
consist of a final report and poster presentation. The scholars are also supported in submitting their manuscripts to peer-reviewed journals. Faculty or LMA alumni collaborate as research advisors with the scholars in the development of the action research. A sample of past action research questions investigated include the following:

(1) If teachers are exposed to workshops involving questioning techniques to promote problem solving in the classroom, how will this approach impact their questioning skills when teaching students about solving systems of linear equation word problems?

(2) If students are exposed to problem-solving strategies, how will the approach impact the students' ability to solve systems of linear equation word problems?

(3) If I involve parents in guiding their children during STEM experiments at home, will the students demonstrate improvement in their understanding and self-efficacy of the engineering design process?

(4) If I involve parents in guiding their children during STEM experiments at home, will the parents demonstrate improvement in their perceptions of self-efficacy to help their children complete STEM experiments?

(5) How will implementing alternative ancient Egyptian computation algorithms using an ethnomathematics context impact fourth-grade marginalized students?

(6) If we use iReady mathematical games to help first- and fourth-grade students learn computation of whole numbers, then will students demonstrate improvement in solving the computation of whole number problems?

(7) If I implement interactive cross-curricular content using Nearpod (n.d.) during remote learning mathematics instruction, then will third-grade students demonstrate improvement in engagement with and understanding of fractions [32]?

(8) If I implement flipped-classroom intervention in a remote classroom environment, then will my AP Calculus students demonstrate improvement on their test scores and grades?

(9) How does explicit instruction in group collaborative skills affect fourth graders' ability to work as a team to create a final product?

(10) How will explicitly teaching collaborative techniques alter fourth graders' ability to work together in an engineering task?

This list is a small sample of the 106 ideas scholars have addressed through their action research projects. The LMA faculty members' primary goal in the action research projects is to encourage the teachers to continuously think about their ability to lead change using data-driven solutions to problems of practice.

\subsection{TMAST Program}

The second program that emerged from another generous gift from the LMCO partnership was the Transition to Mathematics and Science Teaching (TMAST) program. This program is a fast-track Master of Arts program for individuals with interest in becoming teachers as a second career choice who have STEM backgrounds. The LMA leadership team went to the LMCO leadership after the success of the K-8 program in 2004 and received another gift for USD 750,000. This gift was also endowed and received a match from the state Florida for USD 200,000 to address the critical shortages in Central Florida of STEM content teachers in grades 6-12. This program aligns with the emphasis of Johnson et al. in their Handbook of Research on STEM Education for the need to have teachers who know science content and pedagogical skills [16]. This fast but intense preparation of these career changers (who already received 16-32 credits in STEM content) addresses the critical teacher shortages while providing content, mentoring, coaching, funding, and support to decrease the USD 2.2 billion per year churn of novice teachers who enter the field [10,11].

The TMAST teachers in both the science and mathematics track have the same type of support during student teaching and on-the-job learning. As noted by Sutcher et al., keeping mathematics teachers in the classroom is a crisis in public education [33]. In their study, the District of Columbia and 42 states reported the challenges they had with 
mathematics teacher shortages, their plans to reduce pupil/teacher ratios, and how their intention to hire as many mathematics teachers as possible to serve those students was critical, much like what was observed in the Central Florida area in creating the TMAST program. Teacher workforce attrition accounts for the loss of thousands of teachers every year [34]. Interview results from four sites also supported the idea that providing welltailored, continuous professional development could enhance teachers' efficacy, motivation, and retention and was a built-in component of the TMAST program [10]. As noted by Ingersoll and Smith, "beginning teachers who were provided with multiple supports, were less likely to move to other schools and less likely to leave the teaching occupation altogether after their first year" [10] (p. 28). The TMAST program is built on this evidencebased approach to attract career changers to the profession while providing support for retention.

Since 2003, over 100 teachers have completed the TMAST program. These candidates bring both strong content knowledge and professional experiences in the STEM areas to educational settings in grades 6-12. The TMAST program aligns well with the needs of the candidates by providing tracks in the areas of mathematics, biology, chemistry, and physics for middle or secondary school levels. A Noyce grant from the NSF initially supported students in the TMAST program. The grant was successful in recruiting mid-career professionals with mathematics or science backgrounds and helping them become effective mathematics or science middle or secondary school teachers. The Noyce grant also provided a recruitment tool of financial support aligned with the high-quality four-semester pedagogical preparation. The content of these four semesters includes instructional methods, learning theories, development of teaching goals, understanding high-need local educational agencies serving diverse student populations, educational measurement and assessment, and understanding of the educational contexts that impact young adolescent learners. The program also provides salaries and benefits as the TMAST scholars are given on-the-job internship placements once they have a provisional license. This on-the-job fast-track program has led to retention of the TMAST scholars in education. The Noyce grant provided USD 10,000 fellowships on top of the LMA endowment covering tuition, plus mentoring by LMA faculty to support them. Fifteen of the 20 Noyce TMAST graduates remain in teaching positions at low socioeconomic schools today. The design and partnership aspect of the program serves as a national model for other universities interested in implementing sustainable programs to help professionals from the STEM community transition and stay in the teaching profession.

Mathematics and Science Track TMAST. Since all the TMAST candidates have a bachelor's or higher degree in the content areas, the courses for the program focus more on the inquiry of teaching, learning theories, and instructional methods. For example, in the course entitled "Issues and Methods in Secondary School Science Education", TMAST teachers are provided a series of opportunities to learn the 5E learning instructional model [35] in designing a unit plan to promote students' deeper engagement in science and engineering practices [36], develop instructional objectives for each science lesson to include three components (i.e., performance, condition, and criterion), plan and conduct formative and summative assessment to ascertain students' science learning, and use differentiation methods to meet diverse students' needs. Furthermore, TMAST teachers are provided an on-the-job internship to make more connections between the courses and their practices in the classrooms. During this internship, UCF coordinators work closely with TMAST students to support their planning, enacting, interpreting, translating, and (re)enacting processes in authentic learning contexts. The internship supports TMAST teachers in constructing and understanding the substantive relationships between learners, learning, pedagogy, and learning outcomes. See Table 3 for the course sequence for the program. 
Table 3. UCF and Lockheed Martin TMAST program's teaching course sequence. UCF and Lockheed Martin Transition to Mathematics and Science Teaching.

\begin{tabular}{ccc}
\hline Semester & Credits & Courses \\
\hline $\begin{array}{c}1 \\
\text { Summer }\end{array}$ & 9 & $\begin{array}{c}\text { Teaching Middle School Science OR Teaching Middle School Mathematics } \\
\text { Theory and Practice of Teaching ESOL Students in Schools } \\
\text { Content-specific course in mathematics or science content }\end{array}$ \\
\hline $\mathbf{F a l l}$ & 9 & $\begin{array}{c}\text { Literacy Strategies for Middle and Secondary Teaching } \\
\text { Classroom Management for Mathematics and Science Teachers } \\
\text { Internship }\end{array}$ \\
\hline $\begin{array}{c}\text { Spring } \\
\text { Summer }\end{array}$ & 9 & $\begin{array}{c}\text { Reforming Curriculum in Mathematics and Science Education } \\
\text { Principles of Learning and Introduction to Classroom Assessment } \\
\text { Internship }\end{array}$ \\
\hline $\mathbf{9}$ & $\begin{array}{c}\text { Critical Analysis of Social, Ethical, Legal, and Safety Issues Related to Education } \\
\text { Teaching Algebra in Secondary Schools OR Space Science for Educators OR } \\
\text { Environmental Education for Educators } \\
\text { Capstone Seminar in Secondary Education }\end{array}$ \\
\hline
\end{tabular}

\subsection{Enhancement Grants}

Based upon the ongoing success of the academy and the rising cost of tuition, the LMA leadership team approached the LMCO once again and received a third endowment gift in 2012 for USD 500,000 with match eligibility by the state which, to date, has not yet occurred. This gift request was funded for two purposes. The first purpose was to provide additional tuition support from the gift endowed in 1992 to address the rising cost of tuition. The second purpose was to provide past LMA participants who wanted to retool their skills in mathematics or science the chance to attend workshops, conduct innovative practices in their classrooms, attend and present at practitioner conferences, or purchase supplies for mathematics or science projects. A past LMA graduate can compete for a USD 1000 grant. Each application consists of a short essay that explains the purpose and significance of the potential project and a budget outlining how the funds will be spent. Priority is given to applicants with (1) the most time lapsed since graduating from the academy and (2) individuals whose current roles directly impact student learning in mathematics or science. A condition of receiving a grant is the expectation the recipient will share their learning with current LMA scholars. The Enhancement Scholarship provides a way to ensure life-long learning and leadership of the LMA scholars.

Samples of some of the projects funded at this time include the STEM Bowl Competition in robotics and coding, exploring various resources (e.g., unique joysticks and other evolving devices) to teach engineering design and computer programming, attending a National Science Teacher Association STEM Conference, increasing students' engagement using various web-based technology tools, and taking content courses at UCF to teach comprehensive science. These grants from the endowed gift allow LMA graduates to stay connected to UCF and empower these teacher-leaders with funds to retool their STEM skills throughout their careers.

\section{Current Status of the Program and Partnership}

Since the inception of the program and partnership in 1992, the LMA program has grown substantially. Recently, a newly cemented partnership for teacher retooling and retention was finalized with a local district. Since 1992, teachers attending the program have come from six districts surrounding $\mathrm{UCF}$, all of whom have long-standing relationships with the university. As the incentive to receive a masters or to be nationally board-certified (which was at one time a component of the program) no longer received financial incentives from the state teacher to increase teacher pay, and UCF tuition costs rose simultaneously, the number of teachers entering the $\mathrm{K}-8$ program decreased. The LMA faculty members realizing a need to pivot again to ensure the sustainability of the program looked once 
again at the power of partnerships. The academy partnering with a local district began to explore a pathway to grow the program while meeting the partnership goals and needs in staffing, supporting, and retaining teachers in Title I schools.

A culmination of these discussions resulted in an agreement for the district to match funding from the academy to fully fund the master's degrees of a cadre of 20 teachers in Title I schools. The district also offered a large stipend to teachers in these rich and diverse schools to ensure the students had the best of the best teachers. These schools received numerous applications, and the academy received a rich and diverse pool of outstanding teacher-leaders. This partnership between the district and the academy created the ideal scenario for a new venture. The academy faculty members immediately engaged their corporate partnership with the LMCO to help highlight the outstanding contributions of these teacher-leaders. The first group of teachers invited into this "elite" cohort were presented to the corporate sponsor and the local school board-who was supporting their funding - with each teacher receiving a lab coat (as seen in this article https: / / www.ucf.edu/pegasus/helping-public-school-teachers-earn-free-masters-degree/, accessed on 10 November 2021), highlighting their entrance as K-8 teachers into the STEM fields. This partnership not only increased the retention of these teachers in their positions, as they received $100 \%$ tuition support in return for staying a minimum of 3 years and a pay raise upon completing the master's degree, but most importantly, they felt empowered, appreciated, and entitled to lead. These teachers provided a new mindset in STEM education for the students they were teaching in Title I schools. In return, the university had a large and sustained cohort of teachers with rich experiences (average teaching experience of 7 years), and the diversity of the scholars exceeded the past percentages of diversity ( $46 \%$ reported being from diverse backgrounds) of the LMA program and the university, which is designated as a Hispanic-serving institution (meaning over $25 \%$ of UCF's students in undergraduate enrollment are Hispanic). Today, this partnership continues to fund a cohort annually with funds from the academy, the district, and Title I funding of up to 30 teachers annually. Prior to this new partnership, the interest from the endowment supported approximately 10 teachers per year, showing the power of this expanded partnership, which has tripled the impact in terms of the number of currently enrolled LMA scholars (30 per year).

\section{Future Dreams and Reflections}

The dreams of the LMA faculty members and their partnership districts are to create changes in student learning outcomes in STEM content. As noted by the U.S. Department of Labor (2017), the top 30 occupations to grow the fastest by 2026 are those in STEM fields [37]. This partnership between the LMCO, UCF, and local districts creates opportunities to prepare students in Central Florida for the needs of industry partners in STEM areas. Simultaneously, this newest partnership, working with over 150 teachers to this point in Title I schools, creates the potential for an increased trajectory for the diversity of individuals entering STEM fields. These LMA teacher-leaders in these Title I schools, through their coursework and action research, are agents of change.

This type of direct support to practicing teachers in both the K-8 and TMAST programs also aligns with current U.S. Department of Education initiatives outlined in their roadmap to provide support to teachers in Title I schools for recruitment and retention [38]. Currently, the TMAST scholars primarily work in Title I schools. The LMA faculty members dream of not only better prepared teachers in STEM, but that this program continues to address key variables concerning why teachers leave the field. Many of the teachers in the program stay through retirement. Many may move into district leadership roles of curriculum directors, administrators, or coaches, but the true dream of the program faculty members is that the individuals who graduate stay because, as seen in Table 3, they are better prepared to not leave due to (1) better preparation for the content (e.g., mathematics and science), (2) better preparation in pedagogical and content practices [1], and (3) better preparation to address 
the high rates of stress and burnout [2] due to the ongoing and sustained support of the academy.

The UCF academy faculty members applaud the vision of the LMCO to support universities in helping to prepare stronger teacher-leaders in STEM to deal with shortages in these content areas. The need for a strong STEM workforce is critical in Central Florida, with our increased industries in simulation, space exploration, entertainment, and technology, along with a great migration post-pandemic to this vibrant area of the state. The vision and support of the LMCO, combined with a university in its youth (compared with the ages of other institutions of higher education) and the perfect partnerships of local school district leaders created in 1992, remains vibrant today as a program to impact the children and teachers in Central Florida in STEM areas. Thirty years ago, little did anyone know the exponential, sustained, and eternal impact of this gift based on a "true" partnership model. The ultimate dream is to create additional sustained partnerships to serve the greater good of all of society, as that is truly the purpose of partnerships in education.

Author Contributions: Conceptualization, L.A.D.; validation, L.A.D., M.B.B. and E.O.; formal analysis, L.A.D.; resources, S.G. and E.O.; data curation, L.A.D.; writing-original draft preparation, L.A.D.; writing-review and editing, E.O.; supervision, M.B.B.; project administration, M.B.B., E.O. and S.G.; funding acquisition, L.A.D. and M.B.B. All authors have read and agreed to the published version of the manuscript.

Funding: This program was funded by an endowment from the Lockheed Martin Corporation to the University of Central Florida, with matching funds from the State of Florida Board of Governors, Title 1 funds, and district partnership matching funds.

Institutional Review Board Statement: Ethical review and approval were received by the independent evaluator for the UCF Lockheed Martin Academy who obtained informed consent. The information beyond the evaluation did not involve human subjects.

Informed Consent Statement: Not applicable.

Data Availability Statement: Evaluation data for this program can be obtained Program Evaluation and Educational Research Group (PEER), A Service Center at the University of Central Florida via email to peer@ucf.edu.

Conflicts of Interest: No conflict of interest.

\section{References}

1. Ekstam, U.; Korhonen, J.; Linnanmäki, K.; Aunio, P. Special Education and Subject Teachers' Self-Perceived Readiness to Teach Mathematics to Low-performing Middle School Students. J. Res. in Spec. Educ. Needs. 2018, 18, 59-69. [CrossRef]

2. Rumschlag, K. Teacher Burnout: A Quantitative Analysis of Emotional Exhaustion, Personal Accomplishment, and Depersonalization. Int. Manag. Rev. 2017, 13, 22-36. Available online: http://americanscholarspress.us/journals/IMR/pdf/IMR-1-2017.\%20 pdf/IMR-v13n1art3.pdf (accessed on 12 November 2021).

3. Gess-Newsome, J.A. Model of Teacher Professional Knowledge and Skill Including PCK. In Re-Examining Pedagogical Content Knowledge in Science Education; Berry, A., Friedrichsen, P., Loughran, J., Eds.; Routledge: New York, NY, USA, 2015 ; pp. $28-42$.

4. Rockoff, J.E. The Impact of Individual Teachers on Student Achievement: Evidence from Panel Data. Am. Econ. Rev. 2004, 94, 247-252. [CrossRef]

5. Cheuk, T. Discourse Practices in the New Standards: The Role of Argumentation in Common Core-era Next Generation Science Standards Classroom for English Language Learners. Elect. J. Sci. Educ. 2016, 20, 92-111.

6. National Center for Education Statistics. Fast Facts: English Language Learners; Institute of Education Sciences, U.S. Department of Education: Washington, DC, USA, 2015. Available online: https:/ /nces.ed.gov / fastfacts / display.asp?id=96 (accessed on 12 November 2021).

7. Windschitl, M.; Thompson, J.; Braaten, M.; Stroupe, D. Proposing a Core Set of Instructional Practices and Tools for Teachers of Science. Sci. Educ. 2012, 96, 878-903. [CrossRef]

8. Banilower, E.R.; Smith, P.S.; Malzahn, K.A.; Plumley, C.L.; Gordon, E.M.; Hayes, M.L. Report of the 2018 NSSME+; Horizon Research Inc.: Chapel Hill, NC, USA, 2018. Available online: https:/ files.eric.ed.gov/fulltext/ED598121.pdf (accessed on 12 November 2021).

9. Collins, J.C.; Porras, J.I. Built to Last: Successful Habits of Visionary Companies; Random House: New York, NY, USA, 1994.

10. Ingersoll, R.M.; Smith, T.M. Do Teacher Induction and Mentoring Matter? NASSP Bull. 2004, 88, 28-40. [CrossRef] 
11. Carver-Thomas, D.; Darling-Hammond, L. Teacher Turnover: Why It Matters and What We Can Do about It; Learning Policy Institute: Palo Alto, CA, USA, 2017. Available online: https:/ / learningpolicyinstitute.org/product/teacher-turnover-report (accessed on 12 November 2021).

12. Phi Delta Kappa. The 51st Annual PDK Poll of the Public's Attitudes toward the Public Schools: Frustration in the Schools Teachers Speak Out on Pay, Funding, and Feeling Valued; Phi Delta Kappa: Arlington, VA, USA, 2019. Available online: https://kappanonline.org/ 51st-annual-pdk-poll-publics-attitudes-toward-the-public-schools / (accessed on 12 November 2021).

13. Margot, K.C.; Kettler, T. Teachers' Perception of STEM Integration and Education: A Systematic Literature Review. Int. J. STEM Educ. 2019, 6, 2. [CrossRef]

14. Swan, D. Florida's Economy Ranked \#48: 2008 Great Recession; Southeastern Business Association: Jacksonville, FL, USA, 2017.

15. Gonzalez-DeHass, A.R.; Furner, J.M.; Vásquez-Colina, M.D.; Morris, J.D. Pre-service Elementary Teachers' Achievement Goals and Their Relationship to Math Anxiety. Learn. Individ. Differ. 2017, 60, 40-45. [CrossRef]

16. Johnson, C.C.; Mohr-Schroeder, M.J.; Moore, T.J.; English, L.D. (Eds.) Handbook of Research on STEM Education; Routledge: London, UK, 2020.

17. Dieker, L.A.; Berg, C. Collaborative Program Development between Secondary Science, Mathematics and Special Educators. Teac. Educ. Sp. Educ. 2002, 25, 92-99. [CrossRef]

18. Hackling, M.; Smith, P.; Murcia, K. Talking Science: Developing a Discourse of Inquiry. Teach. Sci. 2010, 56, 17-22.

19. Gee, J.P. How to Do Discourse Analysis: A Toolkit; Routledge: New York, NY, USA, 2011.

20. Hayden, E.; Baird, M.E.; Singh, A. Learning the Words and Knowing the Concepts: An In-depth Study of One Expert Teacher's Use of Language as a Cultural Tool to Support Inquiry. Literacy 2019, 54, 18-28. [CrossRef]

21. Swan, B.; Duff, P. Lockheed Martin/UCF Academy: K-8 Program Evaluation Report (Rep. No. PEER-LMA2010.1-Y12S); University of Central Florida, Program Evaluation and Educational Research Group (PEER): Orlando, FL, USA, 2019.

22. UCF FACTS. UCF Facts: 2020-2021. 2021. Available online: https:/ / www.ucf.edu/about-ucf/facts/ (accessed on 12 November 2021).

23. Shulman, L.S. Knowledge and Teaching: Foundations for the New Reform. Harv. Educ. Rev. 1987, 57, 1-22. [CrossRef]

24. Parker, J.; Heywood, D. Exploring the Relationship between Subject Knowledge and Pedagogic Content Knowledge in Primary Teachers' Learning about Forces. Int. J. Sci. Educ. 2000, 22, 89-111. [CrossRef]

25. Denisova, E.K.; Bell, C.; Covaleskie, K. Evolving the Physics Mindset: Changing Perceptions and Attitudes toward the Teaching and Learning of Physical Science. Sci. Child. 2019, 56, 74-78.

26. Mills, G. Action Research: A Guide for the Teacher Researcher, 5th ed.; Pearson: Upper Saddle River, NJ, USA, 2013.

27. McNiff, J. Action Research: Principles and Practice; Routledge: London, UK, 2013.

28. McNiff, J. Writing and Doing Action Research; Sage: London, UK, 2014.

29. Nugent, G.; Malik, S.M.Y.; Hollingsworth, S. Using Action Research to Improve Literacy Instruction in Classrooms around the World: A Practical Guide to Action Research for Literacy Educators; Global Operations Unit, International Reading Association: Washington, DC, USA, 2012. Available online: https://www.literacyeurope.org/wp-content/uploads/2012/12/a-practical-guide-to-actionresearch-for-literacy-.pdf (accessed on 12 November 2021).

30. Reason, P.; Bradbury, H. (Eds.) Handbook of Action Research: Participative Inquiry and Practice; Sage: London, UK, 2001.

31. Sagor, R. Guiding School Improvement with Action Research; Association of Supervision and Curriculum Development: Alexandria, VA, USA, 2020.

32. Nearpod. However You Teach, It's in Nearpod, n.d. Available online: https:// nearpod.com/ (accessed on 12 November 2021).

33. Sutcher, L.; Darling-Hammond, L.; Carver-Thomas, D. A Coming Crisis in Teaching? Teacher Supply, Demand, and Shortages in the US; Learning Policy Institute: Palo Alto, CA, USA, 2016. Available online: https://learningpolicyinstitute.org/product/solvingteacher-shortage (accessed on 12 November 2021).

34. National Academies of Sciences, Engineering, and Medicine. Changing Expectations for the K-12 Teacher Workforce: Policies, Preservice Education, Professional Development, and the Workplace; The National Academies Press: Washington, DC, USA, 2020. [CrossRef]

35. Bybee, R.W. The BSCS 5E Instructional Model: Creating Teachable Moments; NSTA Press: Arlington, VA, USA, 2015.

36. Sinatra, G.M.; Heddy, B.C.; Lombardi, D. The Challenges of Defining and Measuring Student Engagement in Science. Educ. Psychol. 2015, 50, 1-13. [CrossRef]

37. U.S. Department of Labor, Bureau of Labor Statistics. Employment Projections. 2017. Available online: https://www.bls.gov/ spotlight/2017/science-technology-engineering-and-mathematics-stem-occupations-past-present-and-future/home.htm (accessed on 12 November 2021).

38. U.S. Department of Education. Return to School Roadmap. 2021. Available online: https://sites.ed.gov/roadmap/?utm_ content\&utm_medium=email\&utm_name\&utm_source=govdelivery\&utm_term (accessed on 12 November 2021). 